


\title{
MOTILITY AND VIABILITY OF FRIESIAN HOLSTEIN SPERMATOZOA IN THREE DIFFERENT EXTENDER STORED AT $5^{\circ} \mathrm{C}$
}

\author{
R. I. Arifiantini and B. Purwantara \\ Department of Veterinary Clinic, Reproduction and Pathology, \\ Faculty of Veterinary Medicine,Bogor Agricultural University, \\ Darmaga Campus, Bogor 16680 - Indonesia \\ Corresponding E-mail: Iis.arifiantinipurna@gmail.com
}

Received October 6, 2010; Accepted November 18, 2010

\begin{abstract}
The aims of this study was to compare Tris egg yolk and Citrate egg yolk extender and supplementation of fructose on citrate egg yolk on the quality of Friesian Holstein (FH) bull semen stored at $5{ }^{\circ} \mathrm{C}$. Semen was collected from $5 \mathrm{FH}$ bulls using an artificial vagina. The semen were evaluated macroscopic and microscopically. The semen divided into three tubes and extended with Tris egg yolk (TEY), Citrate egg yolk (CEY) or Citrate fructose egg yolk (CFEY). Extended semen was stored at $5{ }^{\circ} \mathrm{C}$ and evaluate daily for sperm motility and viability. There was no significant differences $(\mathrm{P}>0.05)$ on the sperm viability among three extender, for every time observation during 144 hours of storage. This similar finding found on the sperm motility in all extender for 48 hours of storage. The sperm motility in TEY demonstrated significantly greater $(\mathrm{P}<0.05)$ than in CFEY and CEY extender at 72 to 120 hours storage. In the end of storage, sperm motility in TEY $(35.2 \pm 4.1 \%)$ and CFEY $(33.5 \pm$ $2.71 \%$ ) extender statistically indicated no significant different, and both were greater than CEY. In conclusion, CFEY support the sperm motility as good as TEY of FH bull.
\end{abstract}

Keywords: Citrate, Fructose, FH semen, Tris, citrate

\section{INTRODUCTION}

The use of frozen-thawed semen facilitates distribution of semen world wide and enables screening of bulls for infectious diseases before their semen is used in the field. In rare cases when liquid nitrogen is limited, chilled semen is an alternative used for AI. Various organic salt and acid combinations have been tried for semen preservation, along with proprietary biological buffers. The general requirements for semen diluents are: ionic or non-ionic substances to maintain the osmolarity and to buffer the medium; a source of lipoprotein or high molecular weight material to prevent cold shock, such as egg yolk or milk; glucose or fructose as an energy source; and other additives such as enzymes and antibiotics (Vishwanath and Shannon, 2000).

In years of 1941 the short-term storage extender for bull spermatozoa consisted of $2.9 \%$ sodium citrate and egg yolk, later in year of 1960, Tris-based extender was shown to be superior to sodium citrate for bull semen preservation presumably due to its better buffering capacity. Since then Tris-based extender widely use for semen preservation in bull (Verberckmoes et al., 2005; Arifiantini et al., 2005;2006; 2010), ram (Paulanz et al., 2003; Purdy et al., 2006; NelThemaat et al., 2006; Soylu et al., 2007), buffalo (Rasul et al., 2000; Sukhato et al., 2001), buck (Fukui et al., 2007; ), canine (Schafer-Somi et al. 2006; Hermansson and Linde-Forsberg, 2006) and elephant (Graham et al., 2004), and Spanish ibex (Santiago-Moreno et al., 2006).

Fructose known as a simple sugar and has been used in bull and ram (Vishwanath and Shannon, 2000), canine (Hermansson and LindeForsberg, 2006; Yilziz et al., 2000), stallion (Arifiantini et al., 2009) and buck (Naing et al., 2010) semen preservation. The aims of this study was to compare Tris egg yolk and Citrate egg yolk extender and supplementation of fructose on citrate egg yolk on the quality of FH bull semen storage at $5^{\circ} \mathrm{C}$.

\section{MATERIALS AND METHODS}

A total of five FH bulls belong to Lembang Artificial Insemination Centre were used as sperm 
donors. Semen was collected by using an artificial vagina once a week for 4 weeks. The semen samples were assessed for volume, color, consistency, mass activity, sperm concentration, sperm morphology, sperm viability and percentage of motile sperm. Only ejaculates with a concentration of greater than $800 \times 10^{6}$ sperm $/ \mathrm{mL}$, having $>70 \%$ progressively motile sperm and $>80 \%$ of the sperm with normal morphology were selected for this study. A total of 20 ejaculates were individually process for preservation

\section{Media Preparation}

All chemicals were obtained from Merck, Germany. The cooling extender consisted of three buffer: Tris, Citrate and Citrate fructose (Table 1). All buffer added with 20\% (v/v) egg yolk and antibiotics $(500 \mathrm{IU}$ penicillin and $500 \mu \mathrm{g}$ streptomycin per $\mathrm{mL}$ ). A total of three extender were prepared i.e. Tris egg yolk (TEY), Citrate egg yolk (CEY) and Citrate fructose egg yolk (CFEY).

\section{Semen Evaluation and Processing}

The macroscopic evaluations included semen volume, $\mathrm{pH}$, consistency and color. The microscopic evaluation conducted under microscope 100-400x magnification (Olympus $\mathrm{CH} 20$ ) included mass activity and percentage of progressive motility [0 (not motile) $-100 \%$ (100\% motile], velocity [1 (very slow)-5 (very fast)], viable sperms using eosin-negrosin (Barth and Oko 1989), sperm concentration using Neubauer counting chamber (Kirkman-Brown and Björndahl, 2009) and sperm morphology was assess with carbolfuchsin-eosin (Al-Makhzoomi et al. 2008). After evaluation, each of raw semen was equally divided into three tubes, and diluted in one of three extender; TEY, CEY and CFEY to reach the total semen concentration of $30 \times 10^{6} \%$ $\mathrm{mL}$. Extended semen then stored at $5^{\circ} \mathrm{C}$ for daily evaluation.
The percentage of motile and viable sperm was evaluated every 24 hour, for 144 hours storage. The motile sperm evaluate by mixing the semen gently and placing a $10 \mu \mathrm{L}$ drop of diluted semen on a warm slide and covered with a glass cover slip $(18 \times 18 \mathrm{~mm})$ from five selected representative fields. The mean of the five estimations was recorded as final motility score. Sperm viability was assessed using nigrosin-eosin stain (Bart and Oko, 1989). Placing $10 \mu \mathrm{L}$ drop of diluted semen on a slide and adds with $40 \mu \mathrm{l}$ drop of nigrosin-eosin, and smears on a slide and drying quickly in heating stage $\left(37^{\circ} \mathrm{C}\right)$. Microscopes were selected randomly from ten fields, with total of 200 cells. Individual sperm were recorded as being viable (unstained) or dead (stained).

\section{Data Analysis}

The data were statisticall analyzed for differences among the means by one way analysis of variance. The Turkeys test was use to compare treatment means using statistical soft ware Minitab 14 version.

\section{RESULTS AND DISCUSSION}

Raw semen demonstrated a variation on the quality between the bulls. The mean of semen volume was $6.46 \pm 1.26 \mathrm{~mL}$, cloudy to creamy white in color, $\mathrm{pH}$ was $6.21 \pm 0.07$, and thin to thick in consistency. The mean of mass activity was $2.28 \pm 0.41$ with the percentage of motile and viable sperm were $72.5 \pm 2.3 \%$ and $89.29 \pm 1.51 \%$ respectively. The individual scoring was $3.69 \pm 0.53$ and $1032.00 \pm 232.06 \times 10^{6} / \mathrm{mL}$ in sperm concentration.

The sperm motility and viability demonstrated a gradual decrease during 144 hour storage, which was correlated with the storage time (Table 2 and Table 3). The motile sperm decrease between 4.3 to $8.6 \%$ for every 24 hours observation and viable sperm decrease between

Table 1. Buffer Composition

\begin{tabular}{lccc}
\hline \multicolumn{1}{c}{ Composition } & Tris & Citrate & Citrate fructose \\
\hline Tris-hydroxymethyl-aminomethane $(\mathrm{g})$ & 3.03 & 2.9 & 0 \\
Citric acid monohydrate $(\mathrm{g})$ & 1.78 & 0 & 0 \\
Fructose $(\mathrm{g})$ & 1.25 & 0 & 1.25 \\
Sodium citrate dehydrate $(\mathrm{g})$ & 0 & 0 & 2.32 \\
\hline Aquadest ad $(\mathrm{mL})$ & 100 & 100 & 100 \\
\hline
\end{tabular}


5.1 to $5.8 \%$ (data not show). Sperm require nutrients to maintain their cellular activity; the main source of nutrients is simple carbohydrate, such as fructose or glucose, in seminal plasma or diluents content (Vishwanath and Shannon, 2000). Carbohydrates were broken down through glycolysis or fructolysis to produce ATP and ADP, which are the energy source of sperm; this occurs in the mitochondria located in the sperm's tail to midpiece. Sperm movement stops when no carbohydrate left in semen diluents.

This study demonstrated no significant differences $(\mathrm{P}>0.05)$ on the viability among three extenders, for every time observation during 144 $\mathrm{h}$ of storage (Table 3). The sperm viability associate with the intactness of sperm membrane. The addition of egg yolk which contains phospholipids and lecithin (Bergeron et al., 2004) in all extender might therefore protect the sperm membrane against cold shock (Paulanz et al., 2003). When the sperm plasma membrane damage is located at midpiece, aspartat aminotransferase enzyme (AspAT), which is the main mitochondrial enzyme in ATP production, is released from the cell, and enters the seminal plasma. Loss of AspAT interrupts ATP production and disturbs sperm motility (Colenbrander et al., 1992).

There was no significant on the sperm motility in all extender for 48 hours of storage; the average of sperm motility was $59.5 \pm 4.4 \%$ to $62.3 \pm 2.7 \%$. At 72 until 120 hours of storage, the sperm motility in TEY demonstrate significantly higher $(\mathrm{P}<0.05)$ than in those diluted in CFEY or CEY extender. We also found no significant
$(\mathrm{P}>0.05)$ on the percentage of sperm motility on those extended in CFEY and CEY at 96 as well as at 120 hours of storage. In the end of storage sperm motility in TEY $(35.2 \pm 4.1 \%)$ and CFEY $(33.5 \pm 2.71 \%)$ extender statistically indicated no significant different, both were greater than CEY (Table 2).

The effectiveness of TEY compare to CEY and CFEY on maintained sperm motility in predictable. Several reports have revealed information on Tris egg yolk as an exelent extender for semen preservation in cattle bull, ram, buffalo bull (Purdy et al., 2006; NelThemaat et al., 2006; Soylu et al., 2007; Rasul et al., 2000; Sukhato et al., 2001; Fukui et al., 2007) and canine (Schafer-Somi et al., 2006; Hermansson and Linde-Forsberg, 2006).

In this study it was found that the addition of fructose to Citrate egg yolk extender improves in sperm totality than Citrate egg yolk alone. Fructose and glucose have been known as simple sugar having low molecular weight. Low molecular weight molecules can pass through the plasma membrane of spermatozoa and provide energy to function in metabolism and normal physiological manner (Naing et al., 2010).

Results of this study indicated that spermatozoa stored either in TEY or in CFEY diluents have the same sperm motility after 144 days of storage. This fact proved that CFEY could be use as an alternatif extender for bull semen preservation.

Indonesia lately has $17 \mathrm{AI}$ centre and as far Skim milk, Tris egg yolk or commercial extender were chosen as an extender for bull semen

Table 2. The Sperm Motility of FH Bull Semen Extended in TEY (Tris

Eggyolk), CEY (Citrate Eggyolk) and CFEY (Citrate Fructose Eggyolk)

Extender Stored at $5{ }^{\circ} \mathrm{C}$ for 144 Hours

\begin{tabular}{cccc}
\hline \multirow{2}{*}{ Storage time } & \multicolumn{3}{c}{ Type of Extender } \\
\cline { 2 - 4 } & TEY & CEY & CFEY \\
\hline 0 & $72.50 \pm 2.3^{\mathrm{Aa}}$ & $72.50 \pm 2.30^{\mathrm{Aa}}$ & $72.50 \pm 2.34^{\mathrm{Aa}}$ \\
24 & $69.00 \pm 2.2^{\mathrm{Bb}}$ & $68.00 \pm 2.10^{\mathrm{Bb}}$ & $67.75 \pm 2.40^{\mathrm{Bb}}$ \\
48 & $62.30 \pm 2.7^{\mathrm{Cc}}$ & $59.50 \pm 4.40^{\mathrm{Cc}}$ & $61.25 \pm 1.98^{\mathrm{Cc}}$ \\
72 & $55.00 \pm 1.3^{\mathrm{Dd}}$ & $49.30 \pm 3.00^{\mathrm{Df}}$ & $53.00 \pm 1.68^{\mathrm{De}}$ \\
96 & $47.00 \pm 3.6^{\mathrm{Eg}}$ & $42.00 \pm 3.40^{\mathrm{Ehi}}$ & $44.25 \pm 4.81^{\mathrm{Egh}}$ \\
120 & $42.70 \pm 3.2^{\mathrm{Fj}}$ & $35.80 \pm 2.60^{\mathrm{Fkl}}$ & $38.75 \pm 2.93^{\mathrm{Fjk}}$ \\
144 & $35.20 \pm 4.10^{\mathrm{Gm}}$ & $30.00 \pm 1.53^{\mathrm{Gn}}$ & $33.50 \pm 2.71^{\mathrm{Gm}}$ \\
\hline
\end{tabular}

Different capital superscript in the same column means significantly different $(\mathrm{p}<0.05)$

Different small superscript in the same line means significantly different $(p<0.05)$ 
Table 3. The Sperm Viability of FH Bull Semen Extended in TEY (Tris Eggyolk); CEY (Citrate Eggyolk.) and CFEY (Citrate Fructose Eggyolk) Stored at $5^{\circ} \mathrm{C}$ for 144 Hours

\begin{tabular}{cccc}
\hline \multirow{2}{*}{ Storage time } & \multicolumn{3}{c}{ Type of Extender } \\
\cline { 2 - 4 } & TEY & CEY & CFEY \\
\hline 0 & $89.194 \pm 1.009^{\mathrm{A}}$ & $89.194 \pm 1.009^{\mathrm{A}}$ & $89.194 \pm 1.009^{\mathrm{A}}$ \\
24 & $83.987 \pm 1.267^{\mathrm{B}}$ & $83.85 \pm 1.201^{\mathrm{B}}$ & $83.836 \pm 1.179^{\mathrm{B}}$ \\
48 & $78.917 \pm 1.423^{\mathrm{C}}$ & $77.422 \pm 2.567^{\mathrm{C}}$ & $77.812 \pm 0.982^{\mathrm{C}}$ \\
72 & $73.517 \pm 1.248^{\mathrm{D}}$ & $72.359 \pm 2.353^{\mathrm{D}}$ & $72.364 \pm 1.256^{\mathrm{D}}$ \\
96 & $68.305 \pm 1.47^{\mathrm{E}}$ & $67.294 \pm 1.943^{\mathrm{E}}$ & $67.417 \pm 1.178^{\mathrm{E}}$ \\
120 & $63.221 \pm 1.61^{\mathrm{F}}$ & $62.245 \pm 1.964^{\mathrm{F}}$ & $62.215 \pm 1.161^{\mathrm{F}}$ \\
144 & $56.712 \pm 1.393^{\mathrm{G}}$ & $57.221 \pm 1.829^{\mathrm{G}}$ & $56.836 \pm 0.921^{\mathrm{G}}$ \\
\hline
\end{tabular}

Different capital superscript in the same column means significantly different $(\mathrm{p}<0.05)$

cryopreservation. On the base of this research and considering the chemical price of Citrate cost was less than Tris, it was suggested to use Citrate fructose egg yolk as an alternative extender to produce bull frozen semen.

\section{CONCLUSION}

Base on this research it was concluded that Citrate fructose egg yolk comparable with Tris egg yolk diluent for preserving FH bull semen at $5^{\circ} \mathrm{C}$.

\section{ACKNOWLEDGMENTS}

This work was supported by Pusat Studi Regional Penelitian Biologi Tropika (SEAMEO BIOTROP). Thank to Maidaswar MSi, DVM the head of Lembang Artificial Insemination Centre for providing the facilities of this research, Aminah DVM and Bondan Achmadi-Faculty of Veterinary Medicine for technical assistance.

\section{REFERENCES}

Al-Makhzoomi, A, N. Lundeheim, M. Haard, and J. Rodriguez-Martinez. 2008. Sperm morphology and fertility of progeny-tested AI dairy bulls in Sweden. Theriogenology. 70:682-691

Arifiantini, R.I, T.L.Yusuf and D. Yanti. 2005. Kaji Banding Semen Beku Sapi Friesian Holstein Menggunakan Pengencer dari Berbagai Balai Inseminasi Buatan di Indonesia. Anim.Prod. 7:168-176
Arifiantini, R.I and T.L Yusuf. 2006. Keberhasilan Penggunaan Tiga Pengencer Dalam Dua Jenis Kemasan Pada Proses Pembekuan Semen Sapi Frisien Holstein. Majalah Ilmiah Peternakan. 9:89-93.

Arifiantini, R.I., B. Purwantara, T.L. Yusuf and D. Sajuthi. 2009. Peranan Fruktosa, Rafinosa dan Trehalosa Pada Kriopreservasi Semen Kuda. Med. Pet. 32:155-228.

Arifiantini, R.I and T.L. Yusuf. 2010. Developing of Tris Soy Milk Diluent for Friesian Holstein Bull Frozen Semen. Hayati. Biosci. 17:91-94

Barth, A.D. and R.J. Oko. 1989. Abnormal morphology of bovine spermatozoa. Iowa: Iowa State University Press.

Bergeron, A., M.H. Crête, Y. Brindle and P. Manjunath. 2004. Low-density lipoprotein fraction from hen's egg yolk decreases the binding of the major proteins of bovine seminal plasma tosperm and prevents lipid efflux from the sperm membrane. Biol. Reprod. 70:708-717

Colenbrander, B., A.R. Fazeli., A. Van Buiten. J. Parlevliet and B.M. Gadella. 1992. Assesment of sperm cell membran integrity in the horse. Acta Vet. Scand. Suppl. 88:4958.

Fukui Y, H. Kohno, T. Togari, M. Hiwasa and K. Okabe. 2008. Fertility after insemination using a synthetic semen extender in sheep. J. Reprod. Dev. 54:286-289

Graham L.H., J. Bando, C. Gray and M.M. Buhr. 2004. Liquid storage of Asian (Elephas maximus) sperm at $4{ }^{\circ} \mathrm{C}$. Anim. Reprod. Sci. 80:329-340 
Hermansson, U and C. Linde-Forsberg. 2006. Freezing of stored, chilled dog spermatozoa. Theriogenology. 65:584-593

Kirkman-Brown J and L. Björndahl. 2009. Evaluation of a disposablen plastic Neubauer counting chamber for semen analysis. J. Fert. Ster. 91:627-631

Naing, S.W., H. Wahid, K.M. Azam, Y. Rosnina, A.B. Zuki, S. Kazhala, M.M. Bukara, M. Thein, T. Kyaw and M.M. San 2010. Effect of sugars on characteristics of Boer goat semen after cryopreservation. Anim. Reprod. Sci. 122:23-28

Nel-Themaat, L., G.D. Harding, J.E. Chandler, J.F. Chenevert, P. Damiani, J.M. Fernandez, P.E. Humesa, C.E. Pope and R.A. Godke. 2006. Quality and freezing qualities of first and second ejaculates collected from endangered Gulf Coast Native rams. Anim. Reprod. Sci. 95:251-261

Paulenz, H., Soderquist, L., T. Adnøy, O.H. Fossen and K.A. Berg. 2003. Effect of milkand TRIS-based extenders on the fertility of sheep inseminated vaginally once or twice with liquid semen. Theriogenology. 60:759766

Purdy, P.H. 2006. The post-thaw quality of ram sperm held for 0 to $48 \mathrm{~h}$ at $5^{\circ} \mathrm{C}$ prior to cryopreservation. Anim. Reprod. Sci. 93:114-123

Rasul, Z., M. Anzar., S. Jalali and N. Ahmad. 2000. Effect of buffering systems on postthaw motion characteristics, plasma membrane integrity and acrosome morphology of buffalo spermatozoa. Anim.
Reprod. Sci. 59:31-41

Sukhato, P., S. Thongsodseang, A. Utha and N. Songsasen. 2001. Effects of cooling and warming conditions on post-thawed motility and fertility of cryopreserved buffalo spermatozoa. Anim. Reprod. Sci. 67:69-77

Santiago-Moreno, J., A. Toledano-D1'az, A. Pulido-Pastor, J. Dorado, A. Go'mez-Brunet and A. Lopez-Sebastian. 2006. Effect of egg yolk concentration on cryopreserving Spanish ibex (Capra pyrenaica) epididymal spermatozoa. Theriogenology. 66:1219-1226

Schafer-Somi, S., S. Kluger, E. Knapp, D. Klein and C. Aurich. 2006. Effects of semen extender and semen processing on motility and viability of frozen-thawed dog spermatozoa. Theriogenology. 66:173-182

Soylu, M.K., Z. Nur, B. Ustuner, I. Dogan, H. Sagirkaya, U. Gunay and A.K. Kemal. 2007. Effects of Various Cryoprotective Agents and Extender Osmolality on Post-Thawed Ram Semen. Bull Vet. Inst. Pulawy. 51:241-246

Verberckmoes, S., A. Van Soom., J. Dewulf and A. de Kruif. 2005. Comparison of three diluents for the storage of fresh bovine semen. Theriogenology. 63:912-922

Vishwanath, R and P.S. Shannon. 2000. Storage of bovine semen in liquid and frozen state. Anim. Reprod. Sci. 62:23-53

Yildiz, C., Kaya, A., Aksoy, $\mathrm{M}$ and Tekeli, T 2000. Influence of sugar supplementation of the extender on motility, viability and acrosomal integrity of dog spermatozoa during freezing. Theriogenology. 54:579-585. 